\title{
PENGARUH KUALITAS LAYANAN (SERVICE QUALITY) TERHADAP LOYALITAS MELALUI KEPUASAN PADA MAHASISWA UNIVERSITAS NU SURABAYA
}

\author{
Rusdyana Intan Verriana, Mohamad Yusak Anshori \\ Fakultas Ekonomi dan Bisnis, Universitas Nahdlatul Ulama Surabaya \\ e-mail: rintanve@gmail.com
}

\begin{abstract}
The aim of this research to examine are there impact of service quality to loyalty with satisfaction as intervening variable to students in Nahdlatul Ulama University of Surabaya. Population in this research are students in Nahdlatul Ulama University of Surabaya total of the sample are 368 from 4.536 students. This research are quantitative method with spread 368 questionnaires. The technique analyze of this research use SEM - PLS (partial least square) software. Free variable of this research is service quality $(X)$, intervening variable is satisfaction $(Z)$ and bunch variable is student's loyalty $(Y)$. The result of this research shown that service quality $(X)$ have positive impact and significant to students loyalty $(Y)$ have positive impact and significant with path coefficient 0,67 with $p-v a l u e<0,001$ (significant on 1\%). While service quality $(X)$ have positive impact and significant to students loyalty through satisfaction variable $(\mathrm{Z})$ shown positive impact and significant with path coefficient 0,47 with $p$ - value $<0,001$ ( significant on 1\%).
\end{abstract}

Keywords: service quality, satisfaction, and loyalty

\section{PENDAHULUAN}

Dengan bertumbuh dan berkembangnya industri di bidang jasa, maka masalah layanan menjadi satu hal yang sangat penting karena selalu terkait dengan kebutuhan dan keinginan masyarakat yang semakin populer. Keinginan masyarakat untuk mendapatkan layanan yang baik harus segera direspons dan dipenuhi karena perbaikan layanan akan membuat perusahaan atau instansi tersebut terus tumbuh dan berkembang dengan baik. Menurut Priyono (2006) pemberian layanan yang baik adalah salah satu cara utama untuk tetap maju di tengah persaingan yang ketat, apalagi bagi perusahaan atau instansi yang bergerak di bidang jasa.

Layanan yang berkualitas merupakan senjata utama untuk menjaga keberlangsungan suatu perusahaan atau instansi. Dengan adanya kualitas layanan yang baik maka konsumen baru akan datang dan konsumen yang lama akan menjadi pelanggan.

Konsumen adalah raja, hal tersebut harus ditanamkan oleh pelaku jasa. Sebagaimana halnya seorang raja, maka konsumen harus dilayani sebaik mungkin terutama di masa sekarang di mana masyarakat memiliki banyak pilihan untuk menentukan produk dan jasa yang akan mereka gunakan atau konsumsi.

Salah satu layanan produk jasa yang banyak sekali ditawarkan dan memiliki banyak pilihan adalah produk jasa di bidang layanan pendidikan yang sangat ketat sekali persaingannya. Seperti di Kota Surabaya terdaftar ada 69 universitas di kota ini (www.infosby.asia.com) sehingga persaingan dalam bidang layanan jasa pendidikan di kota Surabaya menjadi semakin ketat, baik lembaga pendidikan yang berstatus negeri maupun swasta. 
Saat ini layanan jasa yang bergerak di bidang layanan pendidikan dengan perkembangannya telah banyak mengalami perubahan. Baik perubahan di bidang penerapan kebijakan pendidikan maupun kurikulum yang diterapkan. Sehingga sebagai pelaku jasa di bidang pendidikan, strategi kualitas layanan merupakan suatu hal yang sangat penting diterapkan, untuk membangun sebuah ciri khas di lembaga pendidikan itu sendiri. Salah satu universitas yang menjadi objek penelitian kualitas layanan terhadap kepuasan dan loyalitas saya adalah universitas Nahdlatul Ulama Surabaya atau yang lebih dikenal dengan nama Unusa.

Unusa didirikan oleh Yayasan Rumah sakit Islam Surabaya (Yarsis), embrio berdirinya berawal sejak tahun 1979 yakni berupa berdirinya Sekolah Perawat Kesehatan (SPK) kemudian dalam perjalanannya mulai tahun 2012 Stikes Yarsis mulai mengajukan proses legalitas peralihan bentuk institusi ke Dikti menjadi universitas, sebuah lompatan besar namun terarah dari proses yang panjang dan akhirnya pada tahun 2013 dengan surat Mendikbud RI No. 265/E/O/2013 pada tanggal 2 Juli 2013 Stikes Yarsis resmi berganti nama menjadi Universitas Nahdlatul Ulama Surabaya (Unusa).

Dalam usia yang masih muda sejak menjadi universitas, Unusa sudah mampu menunjukkan eksistensinya. Eksistensi tersebut bisa dibuktikan dengan pertambahan jumlah mahasiswa per tahunnya. Berikut tabel perkembangan jumlah mahasiswa per tahun.
Tabel

Jumlah Perkembangan Mahasiswa Periode 2013-2015

\begin{tabular}{|c|c|c|}
\hline Nama Program Studi & Periode & $\begin{array}{c}\text { Jumlah } \\
\text { Mahasiswa } \\
\text { Aktif }\end{array}$ \\
\hline \multirow{3}{*}{ Prodi D-III Kebidanan } & 2013 & 688 \\
\hline & 2014 & 588 \\
\hline & 2015 & 486 \\
\hline \multirow{3}{*}{ Prodi D-III Keperawatan } & 2013 & 313 \\
\hline & 2014 & 264 \\
\hline & 2015 & 237 \\
\hline \multirow{3}{*}{ Prodi D-IV Analis Kesehatan } & 2013 & 12 \\
\hline & 2014 & 73 \\
\hline & 2015 & 128 \\
\hline \multirow{3}{*}{ Prodi Profesi Ners } & 2013 & 75 \\
\hline & 2014 & 54 \\
\hline & 2015 & 115 \\
\hline \multirow{2}{*}{ Prodi S1 Akuntansi } & 2014 & 15 \\
\hline & 2015 & 34 \\
\hline \multirow{3}{*}{ Prodi S1 Gizi } & 2013 & 17 \\
\hline & 2014 & 59 \\
\hline & 2015 & 93 \\
\hline \multirow{3}{*}{$\begin{array}{c}\text { Prodi S1 Ilmu Kesehatan } \\
\text { Masyarakat }\end{array}$} & 2013 & 25 \\
\hline & 2014 & 78 \\
\hline & 2015 & 135 \\
\hline \multirow{3}{*}{ Prodi S1 Keperawatan } & 2013 & 502 \\
\hline & 2014 & 570 \\
\hline & 2015 & 589 \\
\hline \multirow{3}{*}{ Prodi S1 Manajemen } & 2013 & 7 \\
\hline & 2014 & 43 \\
\hline & 2015 & 89 \\
\hline \multirow{2}{*}{ Prodi S1 Pendidikan Dokter } & 2014 & 50 \\
\hline & 2015 & 105 \\
\hline \multirow{2}{*}{$\begin{array}{c}\text { Prodi S1 Pendidikan Guru } \\
\text { PAUD }\end{array}$} & 2014 & 157 \\
\hline & 2015 & 287 \\
\hline
\end{tabular}

\begin{tabular}{|c|c|c|}
\hline \multirow{3}{*}{ Prodi S1 Pendidikan Guru SD } & 2013 & 19 \\
\cline { 2 - 3 } & 2014 & 57 \\
\cline { 2 - 3 } & 2015 & 108 \\
\hline \multirow{3}{*}{ Prodi S1 Sistem Informasi } & 2013 & 3 \\
\cline { 2 - 3 } & 2014 & 17 \\
\cline { 2 - 3 } & 2015 & 23 \\
\hline
\end{tabular}

Sumber: Data Kemahasiswaan Universitas Nahdlatul Ulama, 2016 
Dari tabel dapat dilihat bahwa terdapat peningkatan jumlah mahasiswa per tahun dari setiap program studi. Bila terjadi penurunan jumlah mahasiswa maka perlu adanya pengevaluasian terhadap setiap tindakan yang dilakukan oleh Universitas Nahdlatul Ulama Surabaya. Mulai dari pengevaluasian terhadap tindakan pemasaran atau promosi hingga evaluasi kualitas layanan yang diberikan oleh universitas.

Persaingan yang semakin ketat dan kompetitor yang semakin kompetitif, mengharuskan Unusa untuk senantiasa meningkatkan kualitas layanan guna mendapatkan kepercayaan mahasiswa sehingga mahasiswa tidak mudah berpindah pada lembaga pendidikan lainnya.

Oleh karena itu, pengukuran kepuasan akan layanan yang diberikan oleh Unusa harus selalu dilakukan. Hal tersebut bertujuan untuk mengetahui dan merencanakan strategi yang lebih baik di masa mendatang dan untuk meningkatkan kualitas layanan agar dapat memenuhi keinginan dan kebutuhan mahasiswa. Berdasarkan hal tersebut, maka peneliti ingin mengkaji lebih mendalam mengenai pengaruh kualitas layanan yang telah diberikan terhadap loyalitas melalui kepuasan mahasiswa di Universitas Nahdlatul Ulama Surabaya.

\section{KERANGKA TEORETIS}

\section{Manajemen Pemasaran}

Setiap organisasi harus mampu bersikap dinamis dalam merespons perubahan agar mampu tetap bertahan dalam ketatnya persaingan. Perubahan yang terjadi pada lingkungan organisasi bisa saja mengubah kebijakan dan strategi dalam seluruh bidang perusahaan mulai dari keuangan, operasional, sumber daya manusia dan pemasaran. Keseluruhan bidang tersebut merupakan bidang yang memiliki peran penting untuk se- buah perusahaan tetapi bidang pemasaran memainkan peranan yang sangat penting dalam suatu perusahaan karena melalui strategi pemasaran yang baik pada akhirnya akan memberi kontribusi laba yang cukup baik bagi perusahaan.

Pemasaran merupakan penghubung antara kebutuhan masyarakat, untuk memahami kebutuhan tersebut pemasar harus paham tentang kebutuhan konsumen. Untuk memahami kebutuhan konsumen pemasar harus dapat mendefinisikan pemasaran (marketing). Pemasaran (marketing) adalah kegiatan manusia yang ditujukan untuk memuaskan kebutuhan dan keinginan melalui proses pertukaran. Dari definisi ini muncul kegiatan pemasaran yang utama yakni pemasar berusaha untuk memuaskan kebutuhan dan keinginan pasar sasaran mereka.

Untuk memuaskan kebutuhan dan keinginan pasar sasaran para pemasar harus memahami kebutuhan dan keinginan konsumen dengan cara menciptakan kualitas layanan yang baik. Selain menciptakan kualitas layanan yang baik strategi pemasaran yang baik juga merupakan faktor penting untuk memenuhi harapan konsumen sehingga akan tercipta rasa customer satisfaction (kepuasan konsumen). Untuk itu, dalam melakukan kegiatan pemasaran harus dapat memberikan kualitas layanan yang baik agar mampu memenuhi harapan konsumen hingga timbul rasa kepuasan konsumen jika perusahaan tersebut menginginkan usahanya tetap berjalan terus atau menginginkan konsumen mempunyai pandangan yang baik terhadap perusahaan.

\section{Kualitas Layanan}

Pengaruh kualitas layanan terhadap kepuasan dan loyalitas merupakan salah satu topik penelitian yang sudah banyak dilakukan selama lebih dari 40 tahun. Sehingga definisi kualitas 
layanan (service quality) telah banyak disampaikan definisi tentang kualitas berdasarkan tiga sudut pandang pakar kualitas internasional, yaitu mengacu pada pendapat Crosby et al. (dalam Yamit, 2005) antara lain: (1) Deming mendefinisikan kualitas adalah apa pun yang menjadi kebutuhan dan keinginan konsumen; (2) Crosby mempersepsikan kualitas sebagai nihil cacat, kesempurnaan dan kesesuaian terhadap persyaratan; dan (3) Juran mendefinisikan kualitas sebagai kesesuaian terhadap spesifikasi, jika dilihat dari sudut pandang produsen. Sedang menurut Lewis \& Booms dalam Manullang, (2008) berpendapat bahwa kualitas layanan sebagai ukuran seberapa baik tingkat layanan yang diberikan mampu sesuai dengan harapan pelanggan.

Konsumen menilai kualitas layanan berdasarkan persepsi mereka dari hasil teknis yang diberikan yang merupakan proses di mana hasil disampaikan. Menurut Parasuraman dalam Kheng et al. (2010) menyebutkan bahwa layanan berarti derajat perbedaan yang timbul dari proses layanan dan interaksi antara penyedia layanan dengan konsumen.

Pada prinsipnya kualitas layanan berfokus pada upaya pemenuhan kebutuhan dan keinginan konsumen serta ketekatan penyampaiannya untuk menyesuaikan harapan konsumen. Menurut Kotler (2009) kualitas layanan merupakan keseluruhan ciri serta sifat barang dan jasa yang berpengaruh pada kemampuan memenuhi kebutuhan yang dinyatakan maupun yang tersirat. Definisi lain kualitas layanan bahwa kualitas layanan adalah tingkat keunggulan yang diharapkan dan pengendalian atas tingkat keunggulan tersebut untuk memenuhi keinginan konsumen, menurut (Maharani: 2010). Sedang menurut Lewis dan Booms dalam Wijaya (2011), kualitas layanan adalah ukuran seberapa bagus tingkat layanan yang diberikan mampu dan sesuai dengan ekspektasi konsumen.

Kualitas dimulai dari kebutuhan konsumen dan berakhir pada persepsi konsumen. Kualitas jasa (service quality) dibangun atas adanya perbandingan dua faktor utama yaitu persepsi konsumen atas pelayanan yang nyata mereka terima (perceived service) dengan layanan yang sesungguhnya diharapkan atau diinginkan (expected service). Menurut Adhiyanto (2012), menyatakan bahwa kualitas layanan yang baik dalam suatu perusahaan akan dapat memberikan rasa puas terhadap pelanggan. Kualitas layanan merupakan segala kegiatan yang bertujuan untuk memenuhi kebutuhan dan keinginan pelanggan agar sesuai harapan mereka, menurut (Purbarani: 2013).

Selanjutnya, menurut Wyckof dalam Lovelock (2013), kualitas layanan adalah tingkat keunggulan yang diharapkan dan pengendalian atas tingkat keunggulan tersebut untuk memenuhi keinginan pelanggan. Ini jelas mendefinisikan bahwa kualitas berpusat pada konsumen, seorang produsen dapat memberikan kepuasan bila produk atau layanan yang diberikan dapat memenuhi atau melebihi harapan konsumen.

Dari beberapa teori para ahli di atas maka dapat disimpulkan bahwa kualitas layanan adalah suatu interaksi penyampaian jasa untuk memenuhi kebutuhan dengan tingkat keunggulan sehingga sesuai dengan harapan pelanggan.

\section{Dimensi Kualitas Layanan}

Ada beberapa dimensi kualitas layanan jasa yang dapat dipergunakan untuk mengetahui tingkat kualitasnya. Menurut Parasuraman et al yang lebih dikenal SERQUAL dalam Kotler dan Keller (2007) kualitas layanan dapat dilihat dari lima dimensi sebagai berikut. 
1. Bukti langsung (tangibles) merupakan kemampuan suatu perusahaan dalam menunjukkan eksistensinya kepada pihak eksternal.

2. Keandalan (reliability) kemampuan perusahaan untuk memberikan layanan sesuai dengan yang dijanjikan secara akurat dan tepercaya.

3. Ketanggapan (responsiveness) merupakan suatu kebijakan untuk membantu dan memberikan layanan yang cepat (responsive) dan tepat kepada pelanggan dengan penyampaian informasi yang jelas.

4. Jaminan (assurance) merupakan pengetahuan kesopansantunan dan kemampuan para pegawai perusahaan untuk menumbuhkan rasa percaya para pelanggan kepada perusahaan.

5. Merupakan pemberian perhatian yang tulus dan bersifat individual atau pribadi yang diberikan kepada para pelanggan dengan berupaya memahami keinginan konsumen.

Dimensi lain juga dijelaskan oleh Zeithaml, et al. (dalam Yamit, 2005) yang telah melakukan berbagai penelitian terhadap beberapa jenis jasa dan berhasil mengidentifikasi lima dimensi karakteristik yang digunakan oleh para pelanggan dalam mengevaluasi kualitas layanan. Kelima dimensi karakteristik kualitas layanan tersebut adalah sebagai berikut.

1. Reliability (keandalan), yaitu kemampuan dalam memberikan layanan dengan segera dan memuaskan serta sesuai dengan yang telah dijanjikan.

2. Responsiveness (daya tangkap), yaitu keinginan para staf untuk membantu para pelanggan dan memberikan layanan dengan tanggap.

3. Assurance (jaminan), yaitu mencakup kemampuan, kesopanan dan sifat dapat dipercaya yang dimiliki para staf, bebas dari bahaya, risiko ataupun keraguan.
4. Empathy, meliputi kemudahan dalam melakukan hubungan, komunikasi yang baik dan perhatian dengan tulus terhadap kebutuhan pelanggan.

5. Tangibles (bukti langsung) meliputi fasilitas fisik, perlengkapan, pegawai, dan sarana komunikasi.

Sedangkan menurut Schiffman dan Kanuk (2008) dimensi kualitas layanan dirumuskan menjadi sepuluh kategori.

1. Reliability atau keandalan yaitu kemampuan karyawan di dalam suatu perusahaan untuk menyediakan layanan dengan benar pada waktu yang tepat.

2. Responsiveness atau responsif yaitu kesiapan dan kesediaan karyawan di dalam suatu perusahaan dalam memberikan layanan.

3. Competency atau kompetensi yaitu kemampuan dan pengetahuan yang dimiliki oleh karyawan untuk melayani konsumen.

4. Accessibility atau aksesibilitas yaitu perusahaan mampu memberikan kemudahan dalam akses informasi yang merupakan bagian dari komunikasi antara konsumen dengan karyawan maupun perusahaan.

5. Affability atau kesopanan yaitu kemampuan karyawan dalam suatu perusahaan untuk memberikan rasa hormat, kesopanan, maupun keramahan terhadap konsumen.

6. Communications atau komunikasi yaitu informasi yang tidak terbatas sesuai dengan kebutuhan konsumen serta kemampuan karyawan dalam suatu perusahaan untuk mendengarkan keinginan maupun keluhan konsumen.

7. Credibility atau kredibilitas yaitu sikap kejujuran yang tinggi yang dimiliki oleh karyawan sehingga mendukung kepercayaan dan keyakinan dari konsumen. 
8. Secure atau keamanan yaitu kemampuan karyawan untuk memberikan konsumen rasa aman jauh dari bahaya, risiko, atau kerugian.

9. Empathy atau empati yaitu kemampuan karyawan dalam suatu perusahaan untuk dapat mengerti kebutuhan dan keinginan konsumen.

10. Tangible atau fisik yaitu faktor pendukung yang tersedia seperti adanya fasilitas, penampilan karyawan, dan peralatan yang lengkap serta sesuai standar yang dapat digunakan untuk melayani konsumen.

Dari beberapa dimensi di atas dapat disimpulkan bahwa dimensi keandalan (reliability), ketanggapan (responsiveness), bukti langsung (tangibles), empathy dan jaminan (assurance) merupakan dimensi yang sering kali diperhatikan dalam kualitas layanan jasa.

\section{Kepuasan Pelanggan}

Kepuasan konsumen telah menjelma menjadi sebuah kewajiban bagi setiap organisasi bisnis karena tingginya tingkat persaingan menyebabkan kepuasan menjadi suatu hal yang sangat diperhatikan bagi pemasar. Dari sebuah perasaan puas atau ketidakpuasan dapat memengaruhi tingkat profitabilitas perusahaan di masa mendatang. Ketika merasa puas atas layanan yang didapatkan, maka besar kemungkinan mereka akan kembali lagi dan melakukan pembelian yang lain dan mereka juga akan merekomendasikan pada teman-teman dan keluarganya tentang perusahaan tersebut.

Menurut Sarjono (2007) kepuasan adalah perbandingan antara harapan yang diinginkan tentang pelayanan karyawan, kompetensi tenaga ahli yang didukung oleh sarana prasarana dan kepemimpinan dengan apa yang mereka rasakan setelah mendapatkan pelayanan. Tanggapan ini dikaitkan dengan harapan, pengalaman dan hasil konsumsi produk atau jasa. Kepuasan dapat tercipta dari pengalaman dalam mengonsumsi jasa atau produk, jika lembaga dapat memberikan janji sesuai dengan yang diharapkan maka mereka akan merasa puas.

Berbagai tingkat kepuasan dan ketidakpuasan setelah mengalami atau merasakan masingmasing jasa sesuai dengan sejauh mana harapan mereka terpenuhi atau terlampaui. Menurut Zulian (2008), kepuasan merupakan evaluasi purna-beli atau hasil evaluasi setelah membandingkan apa yang dirasakan dengan harapannya. Sedang menurut Lupioadi (2008) menyatakan bahwa kepuasan atau ketidakpuasan adalah respons terhadap evaluasi ketidaksesuaian yang dirasakan antara harapan sebelumnya dan kinerja aktual produk yang dirasakan setelah pemakaiannya. Kepuasan yang tinggi atau kesenangan cenderung akan menyebabkan perilaku positif, terjadinya kelekatan emosional terhadap merek dan juga preferensi rasional sehingga hasilnya adalah kesetiaan (loyalitas) yang tinggi.

Kepuasan adalah sikap positif terhadap layanan lembaga karena adanya kesesuaian antara harapan dari layanan dibandingkan dengan kenyataan yang diterimanya (Sopiatin, 2010). Kepuasan menunjukkan keadaan emosional, reaksi pasca-pembelian yang ditunjukkan dapat berupa kemarahan, ketidakpuasan, kejengkelan atau kesenangan. Menurut Tjiptono (2011) menyatakan bahwa kepuasan merupakan evaluasi purna-beli di mana alternatif yang dipilih sekurang-kurangnya sama atau melampaui harapan, sedangkan ketidakpuasan timbul apabila hasil (outcome) tidak memenuhi harapan.

Kepuasan adalah suatu respons fisiologis, perasaan senang, atau kecewa seseorang yang muncul setelah membandingkan antara persepsi 
atau kesannya terhadap kinerja (hasil) suatu produk dan harapan-harapannya sebelum dan setelah mengonsumsi produk atau jasa tersebut, (Shing: 2012).

Dari beberapa definisi para ahli di atas maka dapat disimpulkan kepuasan adalah suatu respons perasaan yang dirasakan pelanggan di mana apa yang dirasakan lebih dari apa yang mereka harapkan sedangkan ketidakpuasan adalah apa yang dirasakan tidak sesuai dengan apa yang mereka harapkan.

Perlu diperhatikan bahwa harapan berkembang dari waktu ke waktu seiring dengan semakin banyaknya informasi yang diterima serta makin bertambahnya pengalamannya. Pada gilirannya semua ini akan berpengaruh terhadap tingkat kepuasan yang dirasakan.

Mereka (pelanggan) yang merasa puas akan mendatangkan manfaat bagi perusahaan, berikut manfaat kepuasan menurut (Lovelock: 2011).

1. Untuk mengisolasi pelanggan dari persaingan

2. Dapat menciptakan keunggulan yang berkelanjutan.

3. Mengurangi biaya kegagalan untuk menarik mendorong pelanggan kembali.

4. Untuk mendorong loyalitas pelanggan.

5. Pelanggan yang merasa puas secara tidak langsung akan mempromosikan dari mulut ke mulut.

6. Menurunkan biaya pelanggan baru.

\section{Dimensi Kepuasan}

Ada beberapa dimensi kepuasan yang dapat dipergunakan untuk mengetahui tingkat kepuasan konsumen. Menurut Kotler Philip (2009) kepuasan dapat diukur dengan menanyakan secara langsung kepuasan konsumen dengan menggunakan skala sedangkan metode lain dengan meminta responden membuat daftar masa- lah yang dihadapi dan membuat daftar yang disarankan untuk perbaikan (problem analysis).

Adapun indikator yang digunakan untuk mengukur kepuasan menurut Kotler Philip (2009) yaitu pertama dengan mengukur tingkat kualitas yang diberikan apa sudah sesuai dengan yang dijanjikan dan kedua mengukur bagaimana tingkat layanan yang baik dan memberikan kepuasan bagi konsumen.

Sedangkan menurut Kotler dalam Suwardi (2011) ada beberapa dimensi untuk mempertahankan kepuasan konsumen yakni dengan melihat empat dimensi sebagai berikut.

1. Re-purchase: membeli kembali, di mana pelanggan tersebut akan kembali kepada perusahaan untuk mencari barang atau jasa.

2. Menciptakan word of mouth: dalam hal ini pelanggan akan mengatakan hal-hal yang baik tentang perusahaan kepada orang lain.

3. Menciptakan citra merek: pelanggan akan kurang memperhatikan merek dan iklan dari produk pesaing.

4. Menciptakan keputusan pembelian pada perusahaan yang sama: membeli produk lain dari perusahaan yang sama.

\section{Definisi Loyalitas}

Menurut Philip Kotler dan Keller (2007), loyalitas atau kesetiaan didefinisikan sebagai komitmen yang dipegang kuat untuk membeli atau berlangganan lagi produk atau jasa tertentu di masa depan. Loyalitas akan menjadi kunci sukses tidak hanya pada jangka pendek tetapi juga memiliki keunggulan bersaing secara berkelanjutan, meskipun nantinya ada pengaruh situasi dan usaha pemasaran yang berpotensi menyebabkan perubahan perilaku.

Menurut pemahaman umum, loyalitas adalah komitmen yang kuat untuk berlangganan 
kembali atau melakukan pembelian ulang produk atau jasa yang disukai secara konsisten di masa yang akan datang, meskipun pengaruh situasi dan usaha pemasaran mempunyai potensi untuk menimbulkan perilaku berpindah. Pelanggan yang loyal karena puas dan ingin meneruskan hubungan pembelian merupakan ukuran kedekatan pelanggan pada sebuah produk dan merek.

Menurut Ali Hasan (2008), menyatakan bahwa loyalitas sebagai orang yang membeli, khususnya yang membeli secara teratur dan berulangulang. Pelanggan yang loyal sangat berarti bagi badan usaha karena biaya untuk mendapatkan pelanggan baru lebih mahal dari pada memelihara pelanggan lama (Peter dan Olson: 2010).

Menurut Tjiptono dan Chandra (2012), menyatakan bahwa selama ini loyalitas pelanggan kerap kali dikaitkan dengan perilaku pembelian ulang. Keduanya memang berhubungan namun sesungguhnya berbeda. Dalam konteks merek, loyalitas dapat diartikan sebagai cerminan komitmen psikologis terhadap merek tertentu, sedangkan perilaku pembelian ulang semata-mata menyangkut pembelian merek tertentu yang secara berulang kali hal ini terjadi bisa karena satusatunya merek yang tersedia atau hal lain seperti merek yang termurah dan sebagainya.

Ada lima faktor yang memengaruhi loyalitas (Vanessa Gaffar: 2007) dan perusahaan harus memperhatikan kelima faktor tersebut agar mampu menciptakan karakteristik loyalitas.

\section{Kepuasan (satisfaction)}

Kepuasan merupakan pengukuran gap antara harapan dengan kenyataan yang mereka terima atau yang dirasakan.

2. Ikatan emosi (emotional bonding)

Di mana konsumen dapat terpengaruh oleh sebuah merek yang memiliki daya tarik tersendiri sehingga konsumen dapat diidentifikasikan dalam sebuah merek, karena sebuah merek dapat mencerminkan karakteristik konsumen tersebut.

3. Kepercayaan (trust)

Kemauan seseorang untuk memercayakan perusahaan atau sebuah merek untuk melakukan atau menjalankan sebuah fungsi.

4. Kemudahan (choice reduction and habit) Konsumen akan merasa nyaman dengan sebuah kualitas produk dan merek ketika situasi mereka melakukan transaksi memberikan kemudahan.

5. Pengalaman dengan perusahaan (history with company)

Sebuah pengalaman seseorang pada perusahaan dapat membentuk perilaku. Karena ketika mereka mendapatkan layanan yang baik dari perusahaan maka akan mengulangi perilaku pada perusahaan tersebut.

Pelanggan adalah aset perusahaan, sehingga perusahaan harus menjaga dan mempertahankan konsumennya. Menurut Buchari Alma (2007), pelanggan yang loyal memiliki enam manfaat bagi perusahaan sebagai berikut.

1. Pelanggan yang sudah ada memiliki prospek yang lebih besar untuk memberikan keuntungan kepada perusahaan.

2. Biaya yang dikeluarkan perusahaan dalam menjaga dan mempertahankan pelanggan yang sudah ada relatif lebih kecil daripada mencari pelanggan baru.

3. Pelanggan yang percaya kepada suatu lembaga dalam suatu urusan bisnis cenderung akan percaya juga pada urusan bisnis yang lain. Seperti menggunakan lini produk lain.

4. Jika sebuah perusahaan lama memiliki banyak pelanggan lama, maka perusahaan tersebut akan mendapatkan keuntungan karena adanya efisiensi. Karena pelanggan lama sudah tentu tidak akan banyak lagi tuntutan. 
5. Pelanggan lama tentunya telah banyak memiliki pengalaman positif yang berhubungan dengan perusahaan sehingga mengurangi biaya psikologis dan sosialisasi.

6. Pelanggan lama akan berusaha membela perusahaan dan mereferensikan perusahaan tersebut kepada teman maupun lingkungannya.

Dari beberapa teori tentang loyalitas dapat disimpulkan bahwa loyalitas adalah perilaku positif dari seorang pelanggan terhadap produk atau jasa dengan melakukan pembelian berulangulang sekaligus tindakan mengajak orang lain untuk menggunakan produk atau jasa yang sama.

\section{Dimensi Loyalitas}

Menurut Hidayat (2009) loyalitas merupakan komitmen seorang terhadap suatu pasar berdasarkan sikap positif dan tecermin dalam pembelian ulang secara konsisten. Dimensi dari loyalitas tersebut adalah sebagai berikut.

1. Trust merupakan tanggapan kepercayaan konsumen terhadap pasar.

2. Emotion commitment merupakan komitmen psikologi konsumen terhadap pasar.

3. Switching cost merupakan tanggapan konsumen tentang beban yang diterima ketika terjadi perubahan.

4. Word of mouth merupakan perilaku publisitas yang dilakukan konsumen terhadap pasar.

5. Cooperation merupakan perilaku konsumen yang menunjukkan sikap bekerja sama dengan pasar.

\section{METODE PENELITIAN}

\section{Sampel dan Prosedur}

Populasi adalah wilayah generalisasi yang terdiri atas objek atau subjek yang mempunyai kualitas dan karakteristik tertentu yang ditetapkan oleh peneliti untuk dipelajari dan kemudian ditarik kesimpulannya, menurut Sugiyono (2014). Populasi dalam penelitian ini adalah seluruh mahasiswa Universitas Nahdlatul Ulama Surabaya (Unusa) yang jumlah keseluruhan 4.536 mahasiswa dari jumlah angkatan tahun 2013 hingga 2015. Dalam riset ini, teknik pengambilan sampel yang digunakan menggunakan metode purposive sampling dengan kriteria responden yang terpilih adalah angkatan tahun 2013 hingga tahun 2015, karena tiga angkatan tersebut sudah merasakan kualitas layanan cukup lama yang diberikan oleh Universitas Nahdlatul Ulama Surabaya (Unusa).

Penelitian ini menyebarkan 368 kuesioner dengan responden mahasiswa Universitas Nahdlatul Ulama Surabaya. Dari total 368 responden, diketahui bahwa, responden yang berjenis kelamin perempuan lebih banyak mendominasi dalam penelitian ini hingga 75\%, sedangkan yang berjenis kelamin laki-laki hanya 25\%. Kondisi tersebut terjadi karena memang di universitas Nahdlatul Ulama Surabaya mayoritas mahasiswa terbanyak adalah mahasiswa dari program studi keperawatan dan kebidanan yang di mana dalam program studi tersebut mayoritas mahasiswanya didominasi perempuan.

Sedangkan hasil karakteristik demografi berdasarkan usia, responden yang berusia 20 tahun dalam penelitian ini lebih banyak mendominasi hingga $80 \%$, sisanya responden dengan usia > 22 dan 21 tahun. Kondisi tersebut terjadi karena jika dianalisis dari jumlah angkatan mahasiswa per tahun, jumlah mahasiswa tahun 2015 memiliki jumlah terbanyak daripada tahun 2013 dan 2014 dan mayoritas mahasiswa angkatan tahun 2015 berusia 20 tahun.

Dalam penelitian ini responden didominasi oleh mahasiswa dari fakultas keperawatan dan 
kebidanan yakni hingga 65\% dan sisanya dari fakultas kesehatan, fakultas teknik, fakultas ekonomi, fakultas kedokteran, dan fakultas pendidikan. Kondisi tersebut terjadi karena jumlah mahasiswa fakultas keperawatan dan kebidanan memiliki jumlah terbanyak daripada jumlah mahasiswa dari fakultas non keperawatan dan kebidanan. Dengan demikian, persentase untuk penyebaran angket didominasi oleh responden dari fakultas keperawatan dan kebidanan.

Sedangkan jika berdasarkan periode tahun tercatat sebagai mahasiswa di Universitas Nahdlatul Ulama Surabaya didominasi oleh mahasiswa terbanyak dari tahun 2015 yakni 61\%, dan sisanya dari periode tahun 2014 dan 2013. Kondisi ini jelas karena periode tahun 2015 memiliki jumlah mahasiswa terbanyak daripada jumlah mahasiswa tahun 2014 dan 2013.

\section{Variabel Penelitian dan Pengukuran}

Variabel dalam penelitian ini mengacu pada lima dimensi kualitas pelayanan sebagaimana yang dijelaskan oleh Zeithaml dan Bitner (2003) merumuskan lima dimensi kualitas layanan.

1. Tangibles (bukti langsung), merupakan penampilan dan kemampuan sarana dan prasarana fisik dan dapat diandalkan, keadaan lingkungan sekitar adalah bukti nyata dari pelayanan yang diberikan oleh si pemberi jasa seperti gedung bagus, peralatan lengkap dan canggih, kenyamanan ruang, lahan parkir luas dan nyaman dan sebagainya.

2. Reliability (keandalan), merupakan kemampuan untuk memberikan jasa yang dijanjikan dengan terukur dan tepercaya. Kinerja harus sesuai dengan harapan pelanggan yang berarti ketepatan waktu, pelayanan yang sama untuk semua pelanggan dan tanpa kesalahan.

3. Empathy (empati), merupakan pemberian perhatian yang bersifat individual atau pribadi kepada pelanggan dan berupaya untuk memahami keinginan pelanggan.

4. Responsiveness (daya tanggap), merupakan suatu kebijakan untuk membantu memberikan layanan yang cepat kepada pelanggan.

5. Assurance (jaminan), merupakan pengetahuan dan keramahan karyawan serta kemampuan untuk melaksanakan tugas secara spontan yang dapat menjamin kinerja yang baik sehingga menimbulkan kepercayaan dan keyakinan pelanggan.

\section{HASIL DAN PEMBAHASAN}

Sebelum melakukan analisis pengaruh kualitas layanan terhadap loyalitas melalui kepuasan mahasiswa Universitas Nahdlatul Ulama Surabaya, maka dilakukan uji validitas dan reliabilitas pengukuran. Pengukuran Validitas alat ukur (kuesioner) digunakan Pengukuran validitas konstruk dengan menggunakan software SEM-PLS dapat menggunakan cara yaitu convergent validity. Pengukuran convergent validity pada software WarpPLS dengan melihat combined loading dan cross loadings masing-masing indikator, jika terdapat nilai combined loading dan cross loadings $>0,4-0,7$ dan nilai $\mathrm{p}$ signifikan pada < 0,05 maka indikator tersebut dinyatakan valid, menurut (Hair et, al, 2013). Untuk mengukur reliabilitas alat ukur (kuesioner) pengukuran reliabilitas konstruk dengan menggunakan software SEM - PLS dilakukan dengan cara diukur menggunakan composite reliability dan cronbach alpha. Nilai dari composite reliability dan cronbach alpha dinyatakan reliable jika nilai lebih besar dari 0,70 (Sholihin dan Ratmono, 2013).

\section{SEM PLS}

Teknik analisis yang digunakan untuk pengujian hipotesis pada penelitian ini adalah SEM- 
PLS (Partial Least Square) dikembangkan pertama kali oleh Herman Wold sebagai metode umum untuk mengestimasi path model yang menggunakan konstruk laten dengan multiple indicator.

SEM-PLS merupakan metode analisis yang powerful karena dapat diterapkan pada semua skala data, tidak membutuhkan banyak asumsi. Walaupun SEM-PLS dapat juga digunakan untuk mengonfirmasi teori, tetapi dapat juga digunakan untuk menjelaskan ada atau tidaknya hubungan antar variabel laten, menurut Ghozali (2014).

SEM-PLS mempunyai kelebihan yaitu mampu mengestimasi model yang besar dan kompleks dengan ratusan variabel laten dan ribuan indikator. Apabila sebuah penelitian berada dalam situasi kompleksitas yang tinggi dan memiliki ukuran sampel kurang dari 200, maka analisis SEM dengan menggunakan PLS lebih sesuai diterapkan, menurut Ghozali (2014).

Ada banyak sekali software SEM-PLS yang bisa digunakan yaitu PLS-Graph, Smart-PLS, Visual-PLS, Warp-PLS, dan lain-lain, namun dalam penelitian ini penulis menggunakan software Warp-PLS 3.0. Alasan mengapa menggunakan SEM-PLS karena sampel yang digunakan dalam penelitian ini relatif besar dan indikator pengukuran dalam penelitian ini lebih dari 50, (Hair et al.: 2013).

\section{LANGKAH-LANGKAH SEM PLS}

\section{Evaluasi Outer Model}

Outer model adalah model yang menspesifikasikan hubungan antara variabel laten dengan indikator-indikatornya atau bisa dikatakan bahwa outer model mendefinisikan bagaimana setiap indikator berhubungan dengan variabel latennya, (Ghozali: 2008). Tahap evaluasi outer model merupakan tahapan dalam pengukuran variabel yang akan dilakukan uji validitas dan reliabilitas. Uji validitas variabel atau konstruk dalam analisis SEM-PLS terdiri atas dua hal berikut.

a. Convergent validity. Pengukuran pada convergent validity didasarkan pada nilai combined loading dan cross loadings dengan $>0,4-$ 0,7 dan nilai $\mathrm{p}$ signifikan pada $<0,05$ maka indikator tersebut dinyatakan valid, menurut (Hair et, al, 2013).

b. Composite reliability dan cronbach alpha. Pengukuran pada composite reliability dan cronbach alpha merupakan nilai batas yang diterima untuk tingkat reliabilitas dengan kriteria adalah $>0,70$.

\section{Evaluasi Inner Model}

Inner model adalah model yang menspesifikasi hubungan antar-variabel laten atau bisa juga dikatakan inner model menggambarkan hubungan antar-variabel laten berdasarkan substantive theory, Ghozali (2008).

Tujuan dari inner model adalah untuk melihat korelasi antara konstruk yang diukur dengan melihat nilai $R$-square model yang menunjukkan seberapa besar pengaruh antar-variabel dalam model.). Nilai $R$-squared digunakan untuk mengukur tingkat variasi perubahan variabel independen terhadap variabel dependen, maka dari itu semakin tinggi nilai $R$-squared pada suatu model, hal tersebut menunjukkan semakin baik juga model prediksi dari model penelitian yang diajukan (Hartono dan Abdillah, 2014).

Proses pengujian hipotesis dalam penelitian ini dilakukan dengan melihat nilai path coefficients dan P value dari SEM-PLS itu sendiri. Path coefficients digunakan untuk melihat arah hubungan dalam hipotesis penelitian ini. Nilai path coefficients bernilai positif berarti variabel independen berpengaruh positif dengan variabel 
dependen, sedangkan jika nilai koefisien jalur bernilai negatif diartikan maka variabel independen berpengaruh negatif dengan variabel dependen. Hipotesis dalam penelitian ini dikatakan terdukung dengan $p$-value jika memiliki nilai $<0,01$ maka tingkat signifikan adalah $1 \%, p$ value $<0,05$ maka tingkat signifikan adalah 5\% dan jika $p$-value $<0,1$ maka tingkat nilai signifikan adalah $10 \%$.

\section{HASIL ANALISIS SEM PLS}

a. Evaluasi pertama pada outer model adalah convergent validity. Untuk mengukur convergent validity digunakan nilai combined loading dan cross loadings. Suatu indikator dikatakan memenuhi convergent validity jika memiliki nilai dengan $>0,4-0,7$ dan nilai $\mathrm{p}$ signifikan pada $<0,05$ maka indikator tersebut dinyatakan valid, menurut (Hair et al., 2013). Berikut adalah nilai combined loading dan cross loadings masing-masing indikator pada variabel penelitian.

\begin{tabular}{|l|c|c|c|c|c|}
\hline & KL & KM & LM & SE & P Value \\
\hline res1 & $\mathbf{0 , 5 1 5}$ & -0.132 & 0.893 & 0.039 & $<0,001$ \\
\hline res2 & $\mathbf{0 , 5 1 4}$ & -0.159 & 0.838 & 0.04 & $<0,001$ \\
\hline res3 & $\mathbf{0 , 6 3 7}$ & 0.131 & 0.082 & 0.041 & $<0,001$ \\
\hline res4 & $\mathbf{0 , 7 1 6}$ & 0.129 & 0.064 & 0.039 & $<0,001$ \\
\hline res5 & $\mathbf{0 , 7 5 6}$ & 0.101 & -0.028 & 0.034 & $<0,001$ \\
\hline res6 & $\mathbf{0 , 6 9 4}$ & -0.044 & 0.009 & 0.04 & $<0,001$ \\
\hline res7 & $\mathbf{0 , 7 2 9}$ & -0.035 & -0.071 & 0.043 & $<0,001$ \\
\hline res8 & $\mathbf{0 . 7 3 8}$ & -0.231 & -0.338 & 0.041 & $<0,001$ \\
\hline res9 & $\mathbf{0 , 6 8 4}$ & -0.077 & 0.222 & 0.042 & $<0,001$ \\
\hline res10 & $\mathbf{0 , 6 4 8}$ & -0.236 & 0.11 & 0.045 & $<0,001$ \\
\hline res11 & $\mathbf{0 , 6 3 7}$ & -0.142 & 0.412 & 0.049 & $<0,001$ \\
\hline res12 & $\mathbf{0 , 5 5 9}$ & -0.485 & 0.663 & 0.04 & $<0,001$ \\
\hline res13 & $\mathbf{0 , 7 0 9}$ & -0.23 & -0.194 & 0.041 & $<0,001$ \\
\hline res14 & $\mathbf{0 , 6 4 7}$ & 0.033 & -0.179 & 0.045 & $<0,001$ \\
\hline res15 & $\mathbf{0 , 7 6 6}$ & 0.224 & -0.229 & 0.046 & $<0,001$ \\
\hline res16 & $\mathbf{0 , 7 1 3}$ & 0.039 & -0.48 & 0.04 & $<0,001$ \\
\hline res17 & $\mathbf{0 , 7 2 4}$ & 0.19 & 0.096 & 0.047 & $<0,001$ \\
\hline res18 & $\mathbf{0 , 7 1 3}$ & 0.015 & 0.001 & 0.045 & $<0,001$ \\
\hline res19 & $\mathbf{0 , 7 2 6}$ & 0.117 & -0.308 & 0.039 & $<0,001$ \\
\hline a1 & $\mathbf{0 , 5 1 9}$ & -0.22 & 0.535 & 0,044 & $<0,001$ \\
\hline
\end{tabular}

\begin{tabular}{|c|c|c|c|c|c|}
\hline $\mathrm{a} 2$ & 0,529 & -0.127 & 0.565 & 0,048 & $<0,001$ \\
\hline a3 & 0,683 & -0.223 & 0.154 & 0,037 & $<0,001$ \\
\hline $\mathrm{a} 4$ & 0,771 & -0.108 & -0.081 & 0,040 & $<0,001$ \\
\hline a5 & 0,739 & 0.101 & -0.378 & 0,039 & $<0,001$ \\
\hline $\mathrm{a} 6$ & 0,729 & -0.168 & -0.083 & 0,039 & $<0,001$ \\
\hline a7 & 0,562 & -0.659 & 0.527 & 0,043 & $<0,001$ \\
\hline $\mathrm{a} 8$ & 0,697 & -0.29 & -0.127 & 0,042 & $<0,001$ \\
\hline a9 & 0,779 & -0.104 & -0.162 & 0,031 & $<0,001$ \\
\hline $\mathrm{a} 10$ & 0,745 & 0.066 & -0.401 & 0,037 & $<0,001$ \\
\hline a11 & 0,745 & -0.097 & -0.492 & 0,033 & $<0,001$ \\
\hline a12 & 0,780 & -0.151 & -0.199 & 0,036 & $<0,001$ \\
\hline a13 & 0,720 & 0.252 & -0.517 & 0,040 & $<0,001$ \\
\hline a14 & 0,759 & -0.056 & -0.504 & 0,035 & $<0,001$ \\
\hline a15 & 0,808 & 0.256 & -0.554 & 0,038 & $<0,001$ \\
\hline a16 & 0,785 & 0.296 & -0.514 & 0,045 & $<0,001$ \\
\hline a17 & 0,708 & 0.013 & 0.616 & 0,036 & $<0,001$ \\
\hline a18 & 0,688 & -0.064 & 0.36 & 0,040 & $<0,001$ \\
\hline $\mathrm{t} 1$ & 0,583 & -0.004 & 0.382 & 0,048 & $<0,001$ \\
\hline $\mathrm{t} 2$ & 0,652 & 0.337 & -0.107 & 0,046 & $<0,001$ \\
\hline t3 & 0,621 & 0.112 & -0.143 & 0,043 & $<0,001$ \\
\hline $\mathrm{t} 4$ & 0,721 & -0.057 & 0.165 & 0,039 & $<0,001$ \\
\hline t5 & 0,699 & 0.142 & -0.125 & 0,042 & $<0,001$ \\
\hline t6 & 0,745 & -0.364 & 0.353 & 0,043 & $<0,001$ \\
\hline t7 & 0,740 & -0.173 & 0.374 & 0,036 & $<0,001$ \\
\hline $\mathrm{t} 8$ & 0,777 & 0.06 & 0.195 & 0.037 & $<0,001$ \\
\hline t9 & 0,750 & 0.345 & -0.307 & 0.04 & $<0,001$ \\
\hline $\mathrm{t} 10$ & 0,818 & -0.038 & 0.07 & 0.039 & $<0,001$ \\
\hline $\mathrm{t} 11$ & 0,782 & 0.001 & 0.046 & 0.041 & $<0,001$ \\
\hline $\mathrm{t} 12$ & 0,712 & -0.045 & -0.322 & 0.044 & $<0,001$ \\
\hline $\mathrm{t} 13$ & 0,742 & -0.107 & 0.003 & 0.037 & $<0,001$ \\
\hline $\mathrm{t} 14$ & 0,693 & 0.033 & -0.37 & 0.044 & $<0,001$ \\
\hline $\mathrm{t} 15$ & 0,765 & -0.25 & 0.166 & 0.038 & $<0,001$ \\
\hline $\mathrm{t} 16$ & 0,742 & -0.161 & 0.34 & 0.041 & $<0,001$ \\
\hline $\mathrm{t} 17$ & 0,720 & -0.18 & 0.119 & 0.04 & $<0,001$ \\
\hline $\mathrm{t} 18$ & 0,650 & -0.41 & 0.574 & 0.04 & $<0,001$ \\
\hline t19 & 0,622 & -0.321 & 0.287 & 0.048 & $<0,001$ \\
\hline $\mathrm{t} 20$ & 0,678 & -0.373 & 0.542 & 0.039 & $<0,001$ \\
\hline $\mathrm{t} 21$ & 0,669 & 0.144 & -0.472 & 0.038 & $<0,001$ \\
\hline $\mathrm{t} 22$ & 0,767 & 0.011 & -0.119 & 0.04 & $<0,001$ \\
\hline $\mathrm{t} 23$ & 0,677 & 0.112 & -0.321 & 0.044 & $<0,001$ \\
\hline e1 & 0,604 & -0.199 & 0.176 & 0.042 & $<0,001$ \\
\hline $\mathrm{e} 2$ & 0,633 & 0.148 & -0.11 & 0.037 & $<0,001$ \\
\hline e3 & 0,780 & -0.069 & -0.245 & 0.038 & $<0,001$ \\
\hline e4 & 0,766 & 0.224 & -0.326 & 0.037 & $<0,001$ \\
\hline e5 & 0.785 & 0.248 & 0.057 & 0.039 & $<0,001$ \\
\hline e6 & 0.778 & 0.17 & -0.004 & 0.035 & $<0,001$ \\
\hline e7 & 0.828 & 0.317 & -0.056 & 0.039 & $<0,001$ \\
\hline e8 & 0.822 & 0.309 & -0.054 & 0.035 & $<0,001$ \\
\hline rel1 & 0.807 & 0.456 & -0.045 & 0.04 & $<0,001$ \\
\hline rel2 & 0.835 & 0.406 & -0.016 & 0.042 & $<0,001$ \\
\hline rel3 & 0.793 & 0.35 & -0.006 & 0.041 & $<0,001$ \\
\hline rel4 & 0.809 & 0.101 & -0.026 & 0.033 & $<0,001$ \\
\hline
\end{tabular}


Rusdyana Intan Verriana \& Yusak Anshori, Pengaruh Kualitas Layanan (Service Quality) terhadap Loyalitas Melalui Kepuasan pada Mahasiswa Universitas NU Surabaya

\begin{tabular}{|c|c|c|c|c|c|}
\hline rel5 & 0.722 & -0.14 & -0.027 & 0.039 & $<0,001$ \\
\hline rel6 & 0.690 & 0.101 & 0.561 & 0.037 & $<0,001$ \\
\hline res1_2 & 0.060 & 0.726 & 0.317 & 0.041 & $<0,001$ \\
\hline res2_2 & 0.016 & 0.66 & 0.452 & 0.042 & $<0,001$ \\
\hline res3_2 & 0.294 & 0.733 & -0.002 & 0.042 & $<0,001$ \\
\hline res4_2 & 0.179 & 0.641 & -0.063 & 0.042 & $<0,001$ \\
\hline res5_2 & 0.244 & 0.733 & -0.233 & 0.037 & $<0,001$ \\
\hline res6_2 & 0.342 & 0.763 & 0.057 & 0.031 & $<0,001$ \\
\hline res7_2 & 0.176 & 0.784 & 0.018 & 0.039 & $<0,001$ \\
\hline res8_2 & 0.274 & 0.766 & 0.177 & 0.036 & $<0,001$ \\
\hline res9_2 & 0,321 & 0,743 & $-0,091$ & 0,044 & $<0,001$ \\
\hline res10_2 & 0,711 & 0,719 & $-0,284$ & 0,037 & $<0,001$ \\
\hline res11_2 & 0,558 & 0,626 & $-0,323$ & 0,052 & $<0,001$ \\
\hline res12_2 & 0,513 & 0,557 & $-0,012$ & 0,054 & $<0,001$ \\
\hline res13_2 & 0,308 & 0,625 & 0,167 & 0,049 & $<0,001$ \\
\hline res14_2 & $-0,025$ & 0,747 & 0,200 & 0,040 & $<0,001$ \\
\hline res15_2 & $-0,029$ & 0,840 & 0,193 & 0,036 & $<0,001$ \\
\hline res16_2 & $-0,174$ & 0,769 & 0,159 & 0,039 & $<0,001$ \\
\hline res17_2 & 0,300 & 0,783 & 0,235 & 0,033 & $<0,001$ \\
\hline res18_2 & $-0,057$ & 0,748 & 0,092 & 0,034 & $<0,001$ \\
\hline res19_2 & $-0,138$ & 0,759 & 0,001 & 0,037 & $<0,001$ \\
\hline a1_2 & $-0,280$ & 0,661 & $-0,165$ & 0,042 & $<0,001$ \\
\hline$a 2 \_2$ & $-0,129$ & 0,658 & $-0,174$ & 0,048 & $<0,001$ \\
\hline a3_2 & 0,338 & 0,687 & $-0,227$ & 0,044 & $<0,001$ \\
\hline a4_2 & 0,435 & 0,672 & $-0,008$ & 0,043 & $<0,001$ \\
\hline a5_2 & 0,224 & 0,688 & $-0,329$ & 0,046 & $<0,001$ \\
\hline a6_2 & 0,502 & 0,735 & $-0,267$ & 0,046 & $<0,001$ \\
\hline a7_2 & 0,168 & 0,639 & $-0,583$ & 0,042 & $<0,001$ \\
\hline a8_2 & 0,384 & 0,718 & $-0,655$ & 0,040 & $<0,001$ \\
\hline a9_2 & 0,018 & 0,697 & $-0,682$ & 0,038 & $<0,001$ \\
\hline a10_2 & 0,399 & 0,693 & $-0,629$ & 0,045 & $<0,001$ \\
\hline a11_2 & 0,306 & 0,701 & $-0,634$ & 0,033 & $<0,001$ \\
\hline a12_2 & 0,369 & 0,713 & $-0,628$ & 0,038 & $<0,001$ \\
\hline a13_2 & 0,208 & 0,798 & $-0,060$ & 0,035 & $<0,001$ \\
\hline a14_2 & $-0,010$ & 0,782 & $-0,095$ & 0,043 & $<0,001$ \\
\hline a15_2 & 0,255 & 0,708 & $-0,683$ & 0,035 & $<0,001$ \\
\hline a16_2 & 0,158 & 0,793 & $-0,467$ & 0,042 & $<0,001$ \\
\hline a17_2 & 0,155 & 0,733 & $-0,423$ & 0,044 & $<0,001$ \\
\hline a18_2 & $-0,103$ & 0,751 & $-0,356$ & 0,043 & $<0,001$ \\
\hline t1_2 & $-0,269$ & 0,733 & 0,261 & 0,042 & $<0,001$ \\
\hline t2_2 & 0,077 & 0,754 & $-0,017$ & 0,048 & $<0,001$ \\
\hline t3_2 & $-0,149$ & 0,681 & 0,712 & 0,033 & $<0,001$ \\
\hline t4_2 & $-0,151$ & 0,648 & 0,746 & 0,039 & $<0,001$ \\
\hline t5_2 & $-0,440$ & 0,711 & 0,792 & 0,035 & $<0,001$ \\
\hline t6_2 & $-0,008$ & 0,744 & 0,159 & 0,047 & $<0,001$ \\
\hline t7_2 & 0,030 & 0,623 & 0,178 & 0,048 & $<0,001$ \\
\hline t8_2 & 0,053 & 0,745 & 0,015 & 0,040 & $<0,001$ \\
\hline t9_2 & $-0,041$ & 0,791 & $-0,027$ & 0,033 & $<0,001$ \\
\hline t10_2 & $-0,123$ & 0,818 & $-0,013$ & 0,041 & $<0,001$ \\
\hline t11_2 & $-0,288$ & 0,786 & $-0,012$ & 0,046 & $<0,001$ \\
\hline $\mathrm{t} 12 \_2$ & $-0,385$ & 0,844 & $-0,074$ & 0,038 & $<0,001$ \\
\hline $\mathrm{t} 13 \_2$ & $-0,106$ & 0,778 & 0,291 & 0,044 & $<0,001$ \\
\hline
\end{tabular}

\begin{tabular}{|l|c|c|c|c|c|}
\hline t14_2 & $-0,121$ & $\mathbf{0 , 7 2 0}$ & 0,312 & 0,047 & $<0,001$ \\
\hline t15_2 & $-0,294$ & $\mathbf{0 , 7 0 5}$ & 0,489 & 0,037 & $<0,001$ \\
\hline t16_2 & $-0,454$ & $\mathbf{0 , 7 5 7}$ & 0,483 & 0,039 & $<0,001$ \\
\hline t17_2 & $-0,270$ & $\mathbf{0 , 7 1 3}$ & 0,008 & 0,040 & $<0,001$ \\
\hline t18_2 & $-0,259$ & $\mathbf{0 , 7 9 4}$ & 0,326 & 0,039 & $<0,001$ \\
\hline t19_2 & $-0,411$ & $\mathbf{0 , 7 5 0}$ & 0,356 & 0,041 & $<0,001$ \\
\hline t20_2 & $-0,365$ & $\mathbf{0 , 7 2 2}$ & 0,705 & 0,036 & $<0,001$ \\
\hline t21_2 & $-0,181$ & $\mathbf{0 , 7 0 1}$ & $-0,055$ & 0,042 & $<0,001$ \\
\hline t22_2 & $-0,326$ & $\mathbf{0 , 8 2 0}$ & $-0,018$ & 0,044 & $<0,001$ \\
\hline t23_2 & $-0,267$ & $\mathbf{0 , 8 0 8}$ & $-0,032$ & 0,045 & $<0,001$ \\
\hline e1_2 & $-0,236$ & $\mathbf{0 , 7 1 2}$ & 0,337 & 0,047 & $<0,001$ \\
\hline e2_2 & $-0,058$ & $\mathbf{0 , 7 2 0}$ & 0,189 & 0,043 & $<0,001$ \\
\hline e3_2 & $-0,307$ & $\mathbf{0 , 8 0 8}$ & $-0,095$ & 0,044 & $<0,001$ \\
\hline e4_2 & $-0,181$ & $\mathbf{0 , 7 8 5}$ & $-0,403$ & 0,042 & $<0,001$ \\
\hline e5_2 & 0,057 & $\mathbf{0 , 7 6 3}$ & 0,217 & 0,039 & $<0,001$ \\
\hline e6_2 & 0,231 & $\mathbf{0 , 7 6 5}$ & $-0,424$ & 0,035 & $<0,001$ \\
\hline e7_2 & $-0,179$ & $\mathbf{0 , 8 5 9}$ & $-0,079$ & 0,037 & $<0,001$ \\
\hline e8_2 & $-0,146$ & $\mathbf{0 , 8 3 8}$ & $-0,137$ & 0,038 & $<0,001$ \\
\hline rel1_2 & $-0,293$ & $\mathbf{0 , 8 1 2}$ & 0,101 & 0,034 & $<0,001$ \\
\hline rel2_2 & $-0,259$ & $\mathbf{0 , 8 3 7}$ & 0,089 & 0,033 & $<0,001$ \\
\hline rel3_2 & 0,133 & $\mathbf{0 , 8 3 3}$ & $-0,147$ & 0,036 & $<0,001$ \\
\hline rel4_2 & 0,012 & $\mathbf{0 , 7 9 2}$ & $-0,160$ & 0,038 & $<0,001$ \\
\hline rel5_2 & $-0,410$ & $\mathbf{0 , 7 7 0}$ & 0,345 & 0,040 & $<0,001$ \\
\hline rel6_2 & $-0,287$ & $\mathbf{0 , 6 9 7}$ & 0,582 & 0,037 & $<0,001$ \\
\hline lol1 & 0,094 & $-0,135$ & $\mathbf{0 , 8 4 8}$ & 0,045 & $<0,001$ \\
\hline lol2 & $-0,222$ & 0,228 & $\mathbf{0 , 9 0 6}$ & 0,030 & $<0,001$ \\
\hline lol3 & $-0,113$ & 0,188 & $\mathbf{0 , 9 0 3}$ & 0,033 & $<0,001$ \\
\hline lo14 & 0,268 & $-0,313$ & $\mathbf{0 , 8 3 6}$ & 0,041 & $<0,001$ \\
\hline Not & & 0,019 & \\
\hline
\end{tabular}

Note: P Values $<0,05$ are desirable for reflective indicator.

Diketahui bahwa nilai outer loading masingmasing indikator pada variabel kualitas layanan, kepuasan mahasiswa, dan loyalitas semuanya bernilai $>0,50$ dan nilai $\mathrm{p}$ signifikan karena $<0,05$. Dengan berarti indikator-indikator yang digunakan dalam penelitian ini telah menunjukkan convergent validity.

b. Pengujian reliabilitas diukur menggunakan composite reliability dan cronbach alpha. Rule of thumb dari composite reliability dan cronbach's alpha dinyatakan reliable jika bernilai $>0,70$ (Sholihin dan Ratmono, 2013). Berikut adalah tabel nilai composite reliability.

\begin{tabular}{|c|c|c|c|}
\hline Koefisien & KL & KM & LM \\
\hline Composite Reliability & 0,987 & 0,989 & 0,928 \\
\hline Cronbach's Alpha & 0,987 & 0,989 & 0,896 \\
\hline
\end{tabular}


Suatu composite reliability dinyatakan reliable jika nilainya di atas 0,70. Berdasarkan tabel di atas dapat diketahui bahwa nilai composite reliability dan cronbach's alpha untuk setiap konstruk penelitian adalah $>0,70$ hal ini menunjukkan bahwa semua konstruk memenuhi kriteria composite reliability atau dapat dipercaya.

Langkah selanjutnya adalah evaluasi model pengujian hipotesis yang menggunakan software SEM-PLS dilakukan dengan melihat nilai path coefficients dan P value). Nilai koefisien jalur yang menunjukkan nilai positif berarti variabel independen berpengaruh positif dengan variabel dependen, sedangkan untuk nilai koefisien jalur negatif diartikan variabel independen berpengaruh negatif dengan variabel dependen. Berikut ini adalah gambar evaluasi model penelitian.
Hipotesis yang diajukan dalam penelitian ini ada dua. Hipotesis dalam penelitian ini dikatakan terdukung dengan $p$-value $<0,01$ (signifikan pada tingkat 1\%), $p$-value $<0,05$ (signifikan pada tingkat 5\%) serta $p$-value $<0,1$ (signifikan pada tingkat $10 \%)$.

\section{PEMBAHASAN}

Pengaruh Kualitas Layanan Terhadap Loyalitas Mahasiswa

Hasil uji statistik menunjukkan bahwa jawaban responden terhadap indikator kualitas layanan rata-rata adalah sangat setuju, artinya bahwa persepsi mahasiswa terhadap kualitas layanan Universitas Nahdlatul Ulama Surabaya dirasakan sangat baik.

\section{Model Langsung (Direct)}

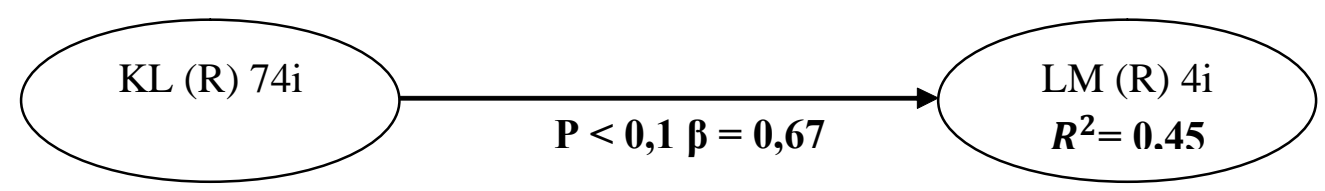

Model Tidak Langsung (Indirect)

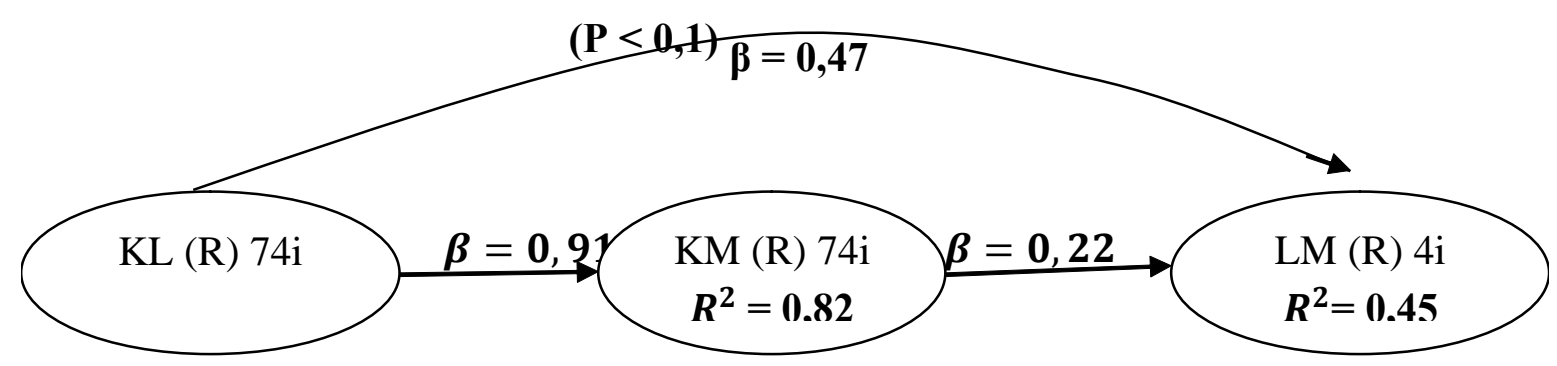


Hasil penelitian menunjukkan bahwa ada pengaruh positif dan signifikan pada hubungan kualitas layanan $(\mathrm{X})$ terhadap loyalitas mahasiswa (Y) di Universitas Nahdlatul Ulama Surabaya. Hal ini ditunjukkan dengan hasil nilai path coefficients sebesar 0,67 dengan P-value $<0,001$ (signifikan pada tingkat 1\%) menunjukkan adanya hubungan searah antara kualitas layanan terhadap loyalitas mahasiswa, artinya semakin tinggi kualitas layanan yang dirasakan maka akan semakin tinggi pula tingkat loyalitas mahasiswa yang akan diberikan, sebaliknya jika semakin rendah kualitas layanan yang dirasakan maka akan semakin rendah juga tingkat loyalitas mahasiswa yang akan diberikan.

Hasil penelitian ini sesuai dengan penelitian yang dilakukan oleh Gusti Ayu Putu Ratih Kusuma (2014) dalam penelitiannya yang berjudul Pengaruh Kualitas Layanan terhadap Kepuasan dan Loyalitas Nasabah PT BPR HOKI di Kabupaten Tabanan yang menunjukkan terdapat pengaruh yang positif dan signifikan antara kualitas layanan terhadap loyalitas pelanggan. Kumar et al. (2009) menyatakan bahwa kualitas layanan yang baik akan menghasilkan kepuasan pelanggan yang tinggi yang dapat meningkatkan loyalitas pelanggan. Manjunath dan Aluregowda (2013) menunjukkan kualitas layanan merupakan elemen penting untuk menciptakan kepuasan dan loyalitas pelanggan. Sehingga dalam mengambil kebijakan untuk meningkatkan loyalitas mahasiswa diharapkan memperhatikan kualitas layanan karena variabel ini berpengaruh positif dan signifikan terhadap loyalitas, Ehigie dalam Ladhari et al. (2011) juga mengemukakan bahwa kualitas layanan dan kepuasan adalah predikator penting dari loyalitas mahasiswa di Universitas Nahdlatul Ulama Surabaya.

\section{Pengaruh Kualitas Layanan Terhadap Loyalitas} Melalui Kepuasan Mahasiswa

Hasil penelitian menunjukkan bahwa ada pengaruh positif dan signifikan pada hubungan kualitas layanan (KL) terhadap loyalitas (LM) melalui kepuasan mahasiswa (KM) di Universitas Nahdlatul Ulama Surabaya. Hal ini ditunjukkan dengan nilai path coefficients sebesar 0,47 dengan $P$-value $<0,001$ (signifikan pada tingkat $1 \%)$ menunjukkan bahwa adanya hubungan mediasi parsial antara kualitas mahasiswa terhadap loyalitas mahasiswa melalui kepuasan mahasiswa. Hasil dari penelitian ini didukung dengan hasil penelitian sebelumnya dilakukan oleh Gusti Ayu Putu Ratih Kusuma (2014) dalam penelitiannya yang berjudul Pengaruh Kualitas Layanan terhadap Kepuasan dan Loyalitas Nasabah PT. BPR HOKI di Kabupaten Tabanan bahwa kepuasan pelanggan berpengaruh positif dan signifikan terhadap loyalitas pelanggan.

Kepuasan pelanggan yang baik memberikan suatu dorongan kepada pelanggan untuk menjalin hubungan yang kuat dengan perusahaan. Pada jangka panjang, ikatan ini memungkinkan perusahaan untuk memahami harapan serta kebutuhan mahasiswa. Mahasiswa yang puas akan melakukan promosi gratis terhadap jasa yang telah diterimanya. Begitu sebaliknya, apabila mahasiswa merasa kurang puas dengan pelayanan yang diberikan universitas maka akan muncul terrorist customer yaitu mahasiswa berbicara mengenai hal yang negatif mengenai universitas dikarenakan tidak puas terhadap pelayanan yang diperoleh, maka hal ini perlu diwaspadai oleh Universitas Nahdlatul Ulama Surabaya.

\section{SIMPULAN DAN SARAN}

Berdasarkan hasil analisis kualitas layanan berpengaruh positif dan signifikan terhadap ke- 
puasan mahasiswa. Artinya mahasiswa sudah merasa puas dengan kualitas layanan yang diberikan. Tetapi ada beberapa variabel penelitian yang perlu diperbaiki, karena saat peneliti menyebarkan kuesioner dan mengolah hasil ada sebagian responden yang rata-rata menjawab tidak setuju (TS) atau sangat tidak setuju (STS) terhadap layanan responsiveness (daya tanggap) yang diberikan oleh pegawai administrasi, seperti bagian tata usaha dan bagian keuangan. Selain variabel responsiveness (daya tanggap), pada variabel tangible (bentuk fisik) rata-rata jawaban juga menunjukkan jawaban tidak setuju (TS) dan sangat tidak setuju (STS) terhadap layanan kebersihan lingkungan, layanan fasilitas pembelajaran, layanan pegawai administrasi keuangan dan tata usaha, serta ketersediaan fasilitas pendukung seperti wi-fi, lahan parkir, laboratorium, perpustakaan, kantin, toilet dan layanan sistem informasi akademik (SIM). Untuk perbaikan pada dimensi daya tanggap dapat dimulai dengan pelatihan customer service untuk bagian administrasi keuangan dan tata usaha. Karena mahasiswa menginginkan layanan yang tidak hanya cepat tanggap dan jelas dalam pemberian informasi tetapi juga berharap dilayani dan didengar keluhannya dengan ramah. Sedangkan untuk perbaikan pada dimensi bukti fisik dapat dimulai dengan perbaikan fasilitas yang lebih baik lagi. Misalkan menambah koleksi buku di perpustakaan, menambah kecepatan akses wi-fi di universitas, menyediakan kantin sesuai dengan harga kantong mahasiswa, menyediakan lahan parkir yang luas dan aman. Universitas merupakan usaha yang bergerak di bidang jasa dan yang mereka hadapi adalah manusia. Manusia mempunyai harapan dan ketika harapan tidak sesuai kenyataan maka hal tersebut akan mengecewakan atau menimbulkan perasaan tidak puas. Sehingga penting bagi Universitas Nahdlatul Ulama Surabaya untuk meningkatkan kualitas layanan dan menjaga dimensi yang ada pada kualitas layanan agar mahasiswa merasa puas dan akan loyal terhadap universitas.

\section{DAFTAR RUJUKAN}

Caruana, Albert. 2002. Service Loyalty: The effects of service quality and the mediating role of customer satisfaction. European journal of marketing.

Alma, Buchari. 2004. Manajemen Pemasaran dan Pemasaran Jasa. Bandung: CV Alfabeta. Tjiptono, Fandy. 2005. Pemasaran Jasa. Cetakan Pertama. Malang: Bayumedia Publishing. Priyono, Agung. 2006. Pelayanan Satu Atap sebagai Strategi Pelayanan Prima di Era Otonomi Daerah. Jurnal Spirit Publik, Vol. 2, Nomor 2, Hlm. 67-74.

Lovelock, CH dan Wright, LK. 2007. Manajemen Pemasaran Jasa. Edisi Bahasa Indonesia. Jakarta: PT Indeks.

Kotler, P. \& Keller, K.L. 2009. Marketing Management ed). New Jersey: Prentice Hall, Inc.

Ascarintya, Praveda. 2011. Analisis Pengarub Kualitas Layanan Terhadap Kepuasan Nasabah (Studi pada Nasabah Debitur PT BPR Satria Pertiwi Semarang). Semarang: Universitas Diponegoro.

Kunto, Sondang Kunto, et al. 2013. Analisa Pengaruh Kualitas Layanan Terhadap Kepuasan Konsumen pada Layanan Drive Thru McDonald's Basuki Rabmat di Surabaya. Surabaya: Universitas Kristen Petra. Widjoyo, Ongko Iksan, et al. 2013. Pengaruh Kualitas Layanan Terhadap Kepuasan Konsumen Pada Layanan Drive Thru Mc. Donald's Basuki Rahmat Surabaya. Surabaya: Universitas Kristen Petra. 
Sholihin, M. and Ratmono, D. 2013. Analisis SEM-PLS dengan WarpPLS 3.0. Yogyakarta: CV Andi Offset.

Tanpa nama. 2014. Info Surabaya (online). (www.infosby.asia, diakses 18 Juni 2014). Sugiyono. 2014. Metode Penelitian Kuantitatif, Kualitatif, dan Kombinasi (Mixed Methods). Bandung: Alfabeta.

Dewi, Gusti Ayu Putu Ratih Kusuma. 2014. Pengaruh Kualitas Pelayanan Terhadap Kepuasan dan Loyalitas Nasabah PT BPR HOKI di Kabupaten Tabanan. Tesis. Universitas Udayana.

Utami, Ida Ayu Inten Surya. 2015. Pengaruh Kualitas Layanan Terhadap Kepuasan Pelanggan Restoran Baruna Sanur. Bali: Universitas Udayana.

Warso, Mukeri Moh, et al. 2016. Pengaruh Relationship Marketing Terhadap Loyalitas Pelanggan dengan Kepuasan Pelanggan sebagai Variabel Intervening (Studi Empiris pada BMT Bina Umat Sejahtera Lasem). Semarang: Universitas Pandanaran.
Haryono, Tri Andi, et al. 2016. Pengaruh Citra Perusahaan dan Kualitas Layanan Terhadap Loyalitas Pelanggan dengan Kepuasan Pelanggan sebagai Variabel Intervening di PT Pelabuhan Indonesia III Semarang. Semarang: Universitas Pandanaran.

Minarsih, M. Maria et al. 2016. Pengaruh Kualitas Produk, Kepercayaan Terhadap Keputusan Pembelian dengan Kepuasan Konsumen sebagai Variabel Intervening (Studi Kasus Pada Susu Bebelac di Giant Hypermarket Karangayu Semarang). Semarang: Universitas Pandanaran.

Warso, Mukeri Moh, et al. 2016. Pengaruh Kualitas Layanan dan Fasilitas Terhadap Kepuasan Pedagang Kaki Lima (Studi Kasus pada Sub Unit PKL Dinas Pasar Kota Semarang). Semarang: Unpand.

Putri Maharani dan Denis Fidita. 2016. Pengaruh Kualitas Pelayanan Badan Penyelenggara Jaminan Sosial (BPJS) Kesehatan Terhadap Loyalitas Pasien Rumah Sakit Rawat Inap di Rumah Sakit Islam (RSI) Jemursari Surabaya. Surabaya: Unusa. 